\title{
The Sustainability of Japan's Government Debt: A Review
}

\author{
Tomomi Miyazaki', Kazuki Onji ${ }^{2}$ \\ ${ }^{1}$ Graduate School of Economics, Kobe University, Kobe, Japan \\ ${ }^{2}$ Graduate School of Economics, Osaka University, Osaka, Japan \\ Email: miyazaki@econ.kobe-u.ac.jp
}

How to cite this paper: Miyazaki, T. and Onji, K. (2017) The Sustainability of Japan's Government Debt: A Review. Theoretical Economics Letters, 7, 1632-1645. https://doi.org/10.4236/tel.2017.76110

Received: July 11, 2017

Accepted: September 12, 2017

Published: September 15, 2017

Copyright (C) 2017 by authors and Scientific Research Publishing Inc. This work is licensed under the Creative Commons Attribution International License (CC BY 4.0).

http://creativecommons.org/licenses/by/4.0/

\begin{abstract}
This paper reviews the literature on the sustainability of Japanese government debt/deficit. First, we offer an overview of the approaches and the key findings on the sustainability analysis. Second, we introduce the arguments of Hoshi and Ito [1], which they predict that foreign investors' share of JGBs could exceed beyond domestic ownership. Finally, we discuss the coordination problem in the JGB market based on the findings of Onji et al. [2] that examine how government withdrawal from the JGBs could roil the market.
\end{abstract}

\section{Keywords}

Sustainability of Government Deficit, Deficit Gamble, Tipping Point of "Crisis," Home Bias, Coordination Problem

\section{Introduction}

Over the last two decades, Japan has been overwhelmed by enormous government debt and significant budget deficits. The central government of Japan has been running budget deficits since the early 1990s and by the end of FY 2016, government debt outstanding accumulated to over 800 trillion yen (approximately USD 8 trillion). As a result, the general government's (central and local) gross debt-to-GDP ratio was as high as $230 \%$ in 2014 (see Figure 1), which is the highest among some developed countries. ${ }^{1}$ Reflecting this public financial condition, both media and practitioners are skeptical about the Japanese government's solvency.

${ }^{1}$ It is also possible to use net financial liability data, which subtracts assets held by the Japanese government. The figure is $130 \%$ of GDP in 2014, which seems to look better than the gross financial assets, and is the second largest, next to Italy. However, please note that it was highest between 2008 and 2013 among the 7 countries listed in Figure 1. 


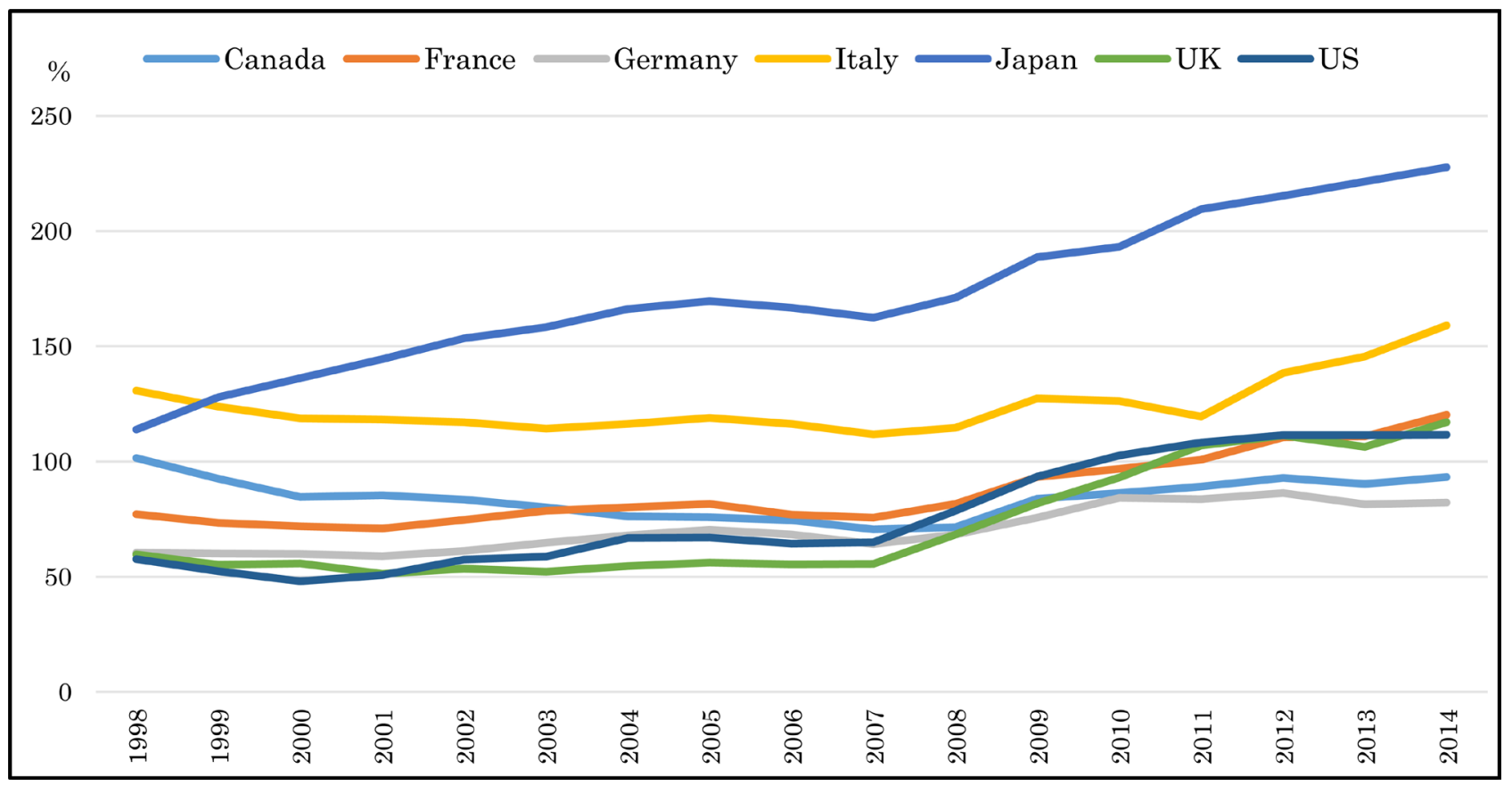

Source: OECD Economic Outlook, Vol. 2016 (1).

Figure 1. Comparison of debt-to-GDP ratio (central and local governments, gross financial liabilities) among some developed countries.

Researchers also have employed various methods to examine the fiscal sustainability of the Japanese government, or whether the government satisfies the intertemporal government budget constraints, giving rise to several strands within the literature, each focusing on a specific method. While specialization has enabled refinement, the technicality of discussion has not been necessarily conducive for a policy audience. Our first goal in this paper is to offer an overview of the approaches and the key findings.

Incidentally, there seem to be no symptoms of a sovereign risk in Japan, following the period of deflation and lower rate of yields on Japanese government bonds (JGBs). Some economists attribute this to the fact that domestic investors share the larger part of the JGB issuance, as shown in Figure 2. However, Tokuoka [3] expects the interest rate on JGBs to rise, as the proportion of non-resident holdings of JGB could eventually increase. Following Tokuoka's [3] results, we cannot rule out the possibility of the JGB yield soaring if foreign investors increase by a fraction. To discuss this, we introduce the arguments of Hoshi and Ito [1], as they predict that foreign investors' share of JGBs could exceed beyond domestic ownership.

Further, a sovereign debt crisis could have occurred even if a country is solvent. Some theoretic analyses on debt and currency crises clarify this. For example, Morris and Shin [4] show that coordination problems among investors can cause them to flee en masse, triggering a debt crisis. Debt holders may be correctively better off by holding on to bonds. However, once a crisis occurs, an agent is worse off by holding on to bonds. Then, the holder would rather sell out 


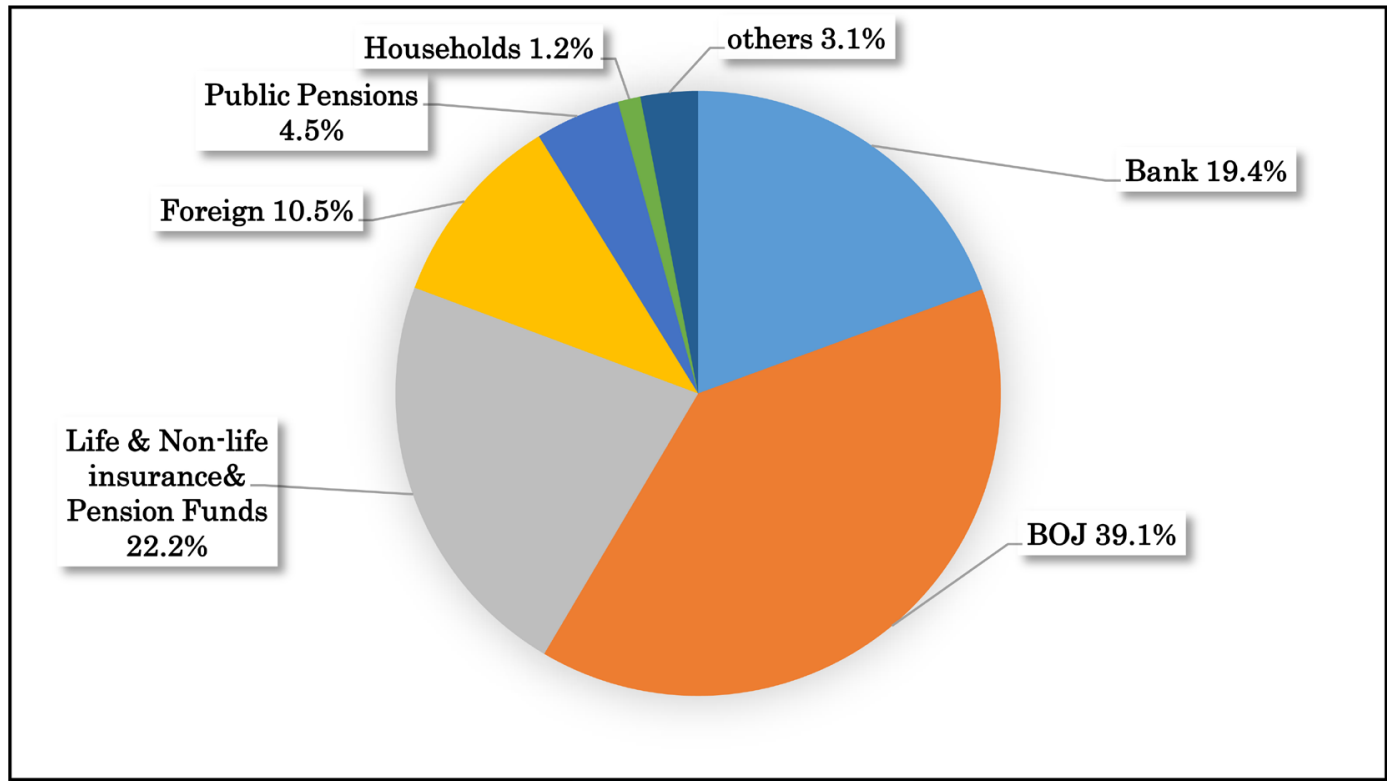

Source: Flow of Funds Statistics, Q4 2016 (Preliminary Estimation), Bank of Japan.

Figure 2. Share of JGB holdings (December 2016).

before the bond becomes worthless. A lack of coordination can lead each debt holder to sell out preemptively, thereby creating a crisis. We discuss this argument based on the findings of Onji et al. [2] that government intervention in Japan could mitigate such coordination problems, and examine how government withdrawal from the JGBs could roil the market.

Section 2 surveys the studies that examine the sustainability of government deficit by focusing on three approaches: the track record of government budget, relevance with economic growth, and the predictions of tax and social security burden to national income or GDP. Sections 3 summarizes the arguments of Hoshi and Ito [1], who examine the relationship between the share of JGB foreign investors and the tipping point of a "fiscal crisis"-they define this as the stage when domestic savings cannot absorb government deficit entirely. Section 4 introduces the issues of a possible sovereign debt crisis even when a country is solvent, emphasizing the active role the government has been playing in the JGB market since its inception, following Onji et al. [2]. Section 5 concludes the paper.

\section{Sustainability Analysis}

In a simple case, the "sustainability" of government budget deficit relates to whether or not the No-Ponzi Game (NPG) condition, equivalent to the intertemporal government budget constraint (IBC), holds. We explain this using Miyazaki [5].

The government's one-period budget constraint is written as follows.

$$
\Delta B_{t}=G_{t}+r_{t} B_{t-1}-R_{t},
$$

where $B_{t}$ is government debt, $R_{t}$ is government revenue, $G_{t}$ non-interest 
spending, and $r B_{t-1}$ interest payment on debt. To put it simply, it is assumed that interest rate $r_{t}$ is stationary around its mean $\mathrm{r}$. Based on this assumption, we define the following: $G_{t}^{*}=G_{t}+\left(r-r_{t}\right) B_{t-1}$. This expression is used to rewrite Equation (1) as follows.

$$
G_{t}^{*}+(1+r) B_{t-1}=R_{t}+B_{t} .
$$

Rewriting Equation (2) for subsequent periods and expressing debt yields:

$$
B_{t}=\frac{1}{(1+r)} S_{t+j+1}+\frac{1}{(1+r)} B_{t+j+1} .
$$

where $S_{t+j+1}=R_{t+j+1}-G_{t+j+1}^{*}$. Then, solving the resulting equations recursively, it yields the following intertemporal budget constraint as follows.

$$
B_{t}=\sum_{j=0}^{\infty} \frac{1}{(1+r)^{j+1}} S_{t+j+1}+\lim _{j \rightarrow \infty} \frac{1}{(1+r)^{j+1}} B_{t+j+1} .
$$

By taking conditional expectations, we can write Equation (4) as:

$$
B_{t}=\sum_{j=0}^{\infty} \frac{1}{(1+r)^{j+1}} E_{t}\left[S_{t+j+1}\right]+\lim _{j \rightarrow \infty} \frac{1}{(1+r)^{j+1}} E_{t}\left[B_{t+j+1}\right] .
$$

Equation (5) demonstrates that initial debt equals the expected present value of future budget surpluses if and only if discounted future debt converge to zero. That is:

$$
B_{t}=\sum_{j=0}^{\infty} \frac{1}{(1+r)^{j+1}} E_{t}\left[S_{t+j+1}\right]
$$

must be equivalent to the following:

$$
\lim _{j \rightarrow \infty} \frac{1}{(1+r)^{j+1}} E_{t}\left[B_{t+j+1}\right]=0
$$

Equation (6) is known as the IBC and Equation (7) as the NPG condition. Intuitively, Equation (6) means that if a government can run sufficient surpluses to repair the initial debt outstanding, then such a government is solvent as it satisfies the NPG condition. The arguments developed in Section 2.1 directly relate to this problem. Further, this is also a basis of all frameworks presented in Sections 2.2 and 2.3.

The approach to examine the sustainability of government deficit is threefold; analyzing the time series properties of the fiscal variables, the relevance with economic growth of the possibility of a "deficit gamble" and the calculation of fiscal surplus to restore sustainability, and the predictions of future tax and social security burden. ${ }^{2}$

\subsection{Is the Japanese Government Behaving as It Should?}

The earliest approach in checking the sustainability of government deficit is to

${ }^{2}$ Many studies have been using these approaches other than the ones introduced in this section. However, even though there are a few exceptions, we would like to focus on papers published in international journals to provide information to researchers in foreign countries. 
see whether the government has been acting prudently by reducing debt when the levels are high. The idea is that the researcher checks the government's record of accomplishment by employing the time series data on public debt and budget surplus to ascertain if the government can pay off the debt eventually. While it is difficult to examine how the budget deficit affects the welfare of economic agents and the financial market, this approach is informative in that researchers can clarify whether or not the government's intertemporal budget constraint holds through an econometric investigation of government budget data. There are two approaches, as elaborated in Bohn [6]: the ad hoc approach and the model-based approach.

The ad hoc approach enables us to examine whether or not fiscal policy is on a path such that the present value of expected future primary surplus equals the initial debt as shown in Equation (6). Typically, researchers examine the cointegration relationship between government revenues $\left(R_{t}\right)$ and total government expenditure (the sum of non-interest spending $\left(G_{t}\right)$ and interest payment on the debt $\left(r B_{t-1}\right)$.

Following Miyazaki [5], to proceed from theory to empirical testing, we take first difference of Equation (4) to obtain

$$
\Delta B_{t}=\sum_{j=0}^{\infty} \frac{1}{(1+r)^{j+1}} \Delta S_{t+j+1}+\lim _{j \rightarrow \infty} \frac{1}{(1+r)^{j+1}} \Delta B_{t+j+1} .
$$

Given $\Delta B_{t}=B_{t}-B_{t-1}$, and using Equation (1), we can rewrite Equation (8) as follows.

$$
G_{t}+r B_{t-1}-R_{t}=\sum_{j=0}^{\infty} \frac{1}{(1+r)^{j+1}} \Delta S_{t+j+1}+\lim _{j \rightarrow \infty} \frac{1}{(1+r)^{j+1}} \Delta B_{t+j+1} .
$$

Given the NPG condition, this equation can be written as shown in Equation (10).

$$
G_{t}+r B_{t-1}-R_{t}=\sum_{j=0}^{\infty} \frac{1}{(1+r)^{j+1}} \Delta S_{t+j+1}
$$

To test whether or not Equation (10) holds, we test the stationarity of $\left(G_{t}+r B_{t-1}-R_{t}\right)$ by imposing $R_{t}, G_{t}$, and $B_{t-1}$ are cointegrated vector $(1,-1,-r)$ (or the primary surplus and debt are cointegrated with a cointegrating vector $(1,-r))$. If we can confirm stationarity among these variables, we can consider the budget deficit or debt as sustainable. ${ }^{3}$

Many papers published during the decade from the mid-1980s to the mid1990s such as Trehan and Walsh [8], Hakkio and Rush [9], and Quintos [10] employ this by conducting the unit root or cointegration test for fiscal data. ${ }^{4}$

Incidentally, a default may not be plausible if the government is running a

\footnotetext{
${ }^{3}$ Please note that there are other researches such as those by Hamilton and Flavin [7], which estimates the No-Ponzi Game conditions directly and whether or not statistically significant. However, following the classification of Bohn [6], here we concentrate on studies using the unit-root or cointegration approach.

${ }^{4}$ Some previous works also confirm the stationarity of a deficit because it is conceptually the same as the cointegration of its components, as mentioned in Bohn [6].
} 
budget surplus despite subsequent accumulation of government debt. The ad hoc approach cannot capture this. Bohn [6] introduces the "model-based sustainability approach" to estimate the reaction function developed by him in 1998. ${ }^{5}$ Bohn [11] estimates the equation below.

$$
s_{t}=\rho d_{t}^{*}+\mu_{t}+\varepsilon_{t},
$$

where $s_{t}$ is the ratio of primary surplus to GDP, $d_{t}^{*}$ is the ratio of initial debt outstanding to GDP, $\mu_{t}$ is other determinants of the primary surplus, and $\varepsilon_{t}$ is disturbance. If $\rho$ is estimated to be positive and statistically significant, we estimate that the budget deficit is sustainable because the government can generate a budget surplus to repay the initial debt. $d_{t}^{*}$ is replaced by the privately held debt-to-GDP ratio at the start of the year in the original econometric analysis by Bohn [11].

How can we rate the Japanese government based on these approaches? Earlier studies [12] [13] present an optimistic picture. Fukuda and Teruyama [12] employ the cointegration method as well as the Hamilton and Flavin's [7] approach, and this research can be a leading paper using the ad hoc approach among the earlier Japanese studies. These researchers examine using data at the central government level for the period from 1965 to 1992-a period of rapid economic growth and before the onset of the prolonged recession ("the lost decade"). They find that the Japanese government debt is sustainable using Perron's [14] unit-root test with a structural break on the residual of the logarithm of government revenues minus the logarithm of the total government expenditures $(\log R-\log G$ ). Doi and Nakazato [13] employ Bohn's [11] approach, noting a high degree of financial integration between the central and local governments and argue that a consolidated budget deficit is a more appropriate unit of analysis. They examine combined data at the central-local government level for the period from 1955 to 1995 and find that the sustainability conclusion is robust to the consolidation of accounts. One contributory factor behind the findings is the tax reforms of 1989 that introduced a value-added tax. Another factor is an institutional restriction until 1975 that prevented the central government from issuing bonds, with a few exceptions, during much of the sample period.

Recent studies, in contrast, are more pessimistic. For an ad hoc approach, Ono [15] examines sustainability for the G-7 countries using quarterly data from 1995 through 2001. He employs Sollis's [16] unit-root test with smooth transition, finding Japan to be the only country where fiscal sustainability does not hold. Doi et al. [17] employ the model-based approach on updated data from 1980 through 2010, and conclude that the Japanese government debt poses serious challenges. ${ }^{6}$

Why is this change in results? One relevant indicator that possibly explains this is Japan's social security expenditure increase due to a rapidly aging popula${ }^{5}$ In terms of terminology, "reaction function approach" may be rather appropriate. However, we follow the term using Bohn [6] to make a comparison with the ad hoc approach.

${ }^{6}$ For a paper using another approach, Ihori et al. [18] employ Hamilton and Flavin's [7] approach, examining quarterly data from 1957 through 1999, and conclude it is unsustainable. 


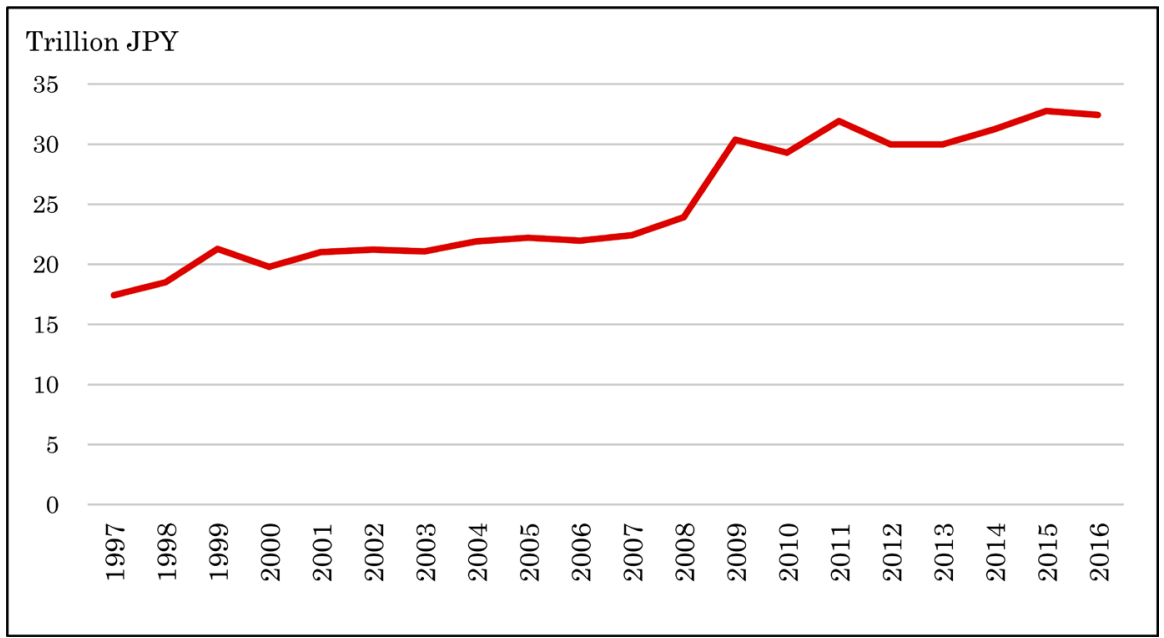

Source: Website of Ministry of Finance, Japan.

Figure 3. Movement of social security related expenditure in the central government budget.

tion. As shown in Figure 3, expenditure related to social security has been continuously increasing, amounting to nearly 32 trillion yen (approximately USD 300 billion) in FY 2016, or almost double the figure in the late 1990s. Social security expenditure undoubtedly has been a burden on Japan's government budget.

\subsection{The "Deficit Gamble" and Prediction of Future Government Surplus}

Incidentally, a record of the past fiscal policy does not provide information about the government's future budgeting path. Therefore, it is necessary to conduct a simulation for future government debt or deficit under the framework assumed in economic growth. Two approaches that complement the time series analysis we have seen so far are considered: examination of the possibility of a "deficit gamble," and forecasting the budget surplus to restore sustainability into the future.

First, we explain a simple framework for "deficit gamble." Here we rewrite Equation (1) as follows.

$$
B_{t}=\left(1+r_{t}\right) B_{t-1}-\left(R_{t}-G_{t}\right) .
$$

By assuming that the primary balance $\left(R_{t}-G_{t}\right)$ is equal to zero, we rewrite Equation (11) in per GDP terms:

$$
b_{t}=\frac{1+r_{t}}{(1+\hat{y})} b_{t-1}
$$

where $b_{t}$ is the debt-to-GDP ratio and $\hat{y}$ is the GDP growth rate. Equation (12) implies that the debt-to-GDP ratio grows by $\frac{1+r_{t}}{(1+\hat{y})}$. Please note that $\frac{1+r_{t}}{(1+\hat{y})}=1+r-\widehat{y}_{t}$. If the economy grows sufficiently faster than the interest rate 
of government bonds, this may reduce the debt-to-GDP, even if the government generates budget deficits.

Ball et al. [19] make a projection of $\frac{1+r_{t}}{(1+\hat{y})}$ into the future by modeling this as a stochastic process in the US to examine the likelihood of a successful "deficit gamble." Oguro [20] reexamines Ball et al.s [19] analysis for France, Germany, Italy, Japan, the US, and the UK. Oguro [20] shows that while five countries, other than Germany, historically satisfy the condition " $\widehat{y}_{t}>r$ " on average, this is not the case for all countries if he conducts the recalculation by adding the standard deviation on uncertainty. He also points out that Japan is the worst among the six countries in terms of the likelihood of failure in the "deficit gamble," which means the debt-to-GDP ratio exceeds a certain level.

The other framework is to predict the level of budget surplus to make the government budget sustainable using certain micro-foundation macroeconomic models.

First, Hosono and Sakuragawa [21] examine using the dynamic stochastic general equilibrium (DSGE) model, which shows that the current primary deficit turns to a surplus in 10 years and increases up to $2.2 \%$ surplus of GDP so that the government debt-to-GDP ratio becomes sustainable. Second, Arai and Nakazawa [22] apply Chalk's [23] overlapping generations (OLG) model. They calculate the level of primary balance ratio to GDP that converges the government debt-to-GDP ratio into some finite level under a certain assumption of economic growth. They show that the government should maintain the primary surplus at $13.8 \%-18.7 \%$ of GDP to make the government budget sustainable, but the primary deficit-to-GDP ratio reaches nearly $8 \%$ in effect. Finally, Arai and Ueda [24] predict the size of economic growth to keep the government budget sustainable by applying Chalk's [23] model. They show that the primary deficit may be unsustainable unless the economic growth rate is more than $5 \%$, an unrealistic figure in contrast to Japan's growth rate in these two decades, according to their setting.

\subsection{Forecasting the Fiscal Burden to Keep Government Budget Sustainable}

Whereas studies presented in Section 2.2 calculate the size of the budget surplus to restore sustainability in the government budget, they do not clarify how nations should bear the burden. In Section 2.3, we introduce some researches that examine this.

A Blanchard-type [25] simulation is the simplest model to predict the size of fiscal burden for keeping government debt and deficit sustainable. In this model, the analyst assumes (1) the growth rate of an economy ( $g$ ) and interest rates ( $\mathrm{r}$ ), (2) a government expenditure stream based on population projections, and (3) an initial debt level to make a projection. The advantage of this approach is that an analyst can identify a country's level of fiscal burden necessary to make the government budget deficit sustainable. Here, the level of "sustainable" govern- 
ment debt is defined as one that stabilizes the debt-to-GDP ratio at the level in the base year (or initial year), which reflects the sustainability defined earlier.

Broda and Weinstain [26], Doi [27], and Doi et al. [17] employ this type of simulation. In a revisionist study, Broda and Weinstain [26] argue that while the gross debt of the Japanese government stands apart from other OECD countries, the net debt does not look alarming. To sustain the fiscal policy, as in a private sector firm, they argue that one should consider both sides of the balance sheet in solvency analysis and examine the behavior of net debt. They conclude that government receipts (tax revenue and social security contributions) to GDP ratio needs to increase to 35 percent from 32.2\%, the average between 1980 and 2000. Doi [27] argues against the definition of net debt employed in Broda and Weinstain [26], noting that some of the asset items such as social security funds cannot be liquidated and should be excluded from the analysis. Doi [27] demonstrates that the government receipts to GDP ratio needs to increase more than the level predicted by Broda and Weinstain [26], to an additional one-percentage point (36\%).

In contrast to these earlier studies, latter studies paint a dismal picture. Doi et al. [17] recalculate the Broda and Weinstain [26]-type simulation until 2100 by setting 2010 as the base year, concluding that the government receipts to GDP ratio should rise to $40 \%-47 \%$ to stabilize the debt-to-GDP ratio.

One limitation with the Blanchard-type simulation is the need to impose assumptions on a number of variables such as the growth rate of an economy. In principle, the sensitivity of predictions to such assumptions can be validated as they can sometimes make the conclusion drawn from the analysis doubtful. An alternative framework is to model an economy to endogenize important variables, using some micro-foundation macroeconomic models.

Here we introduce two research studies. First, Ihori et al. [28] employed a multi-period OLG simulation model developed by Auerbach and Kotlikoff [29]. They modified the Auerbach and Kotlikoff [29] model by incorporating taxes, a public pension scheme, and a public health insurance scheme. They assumed that the government will decrease the debt outstanding until 2023 and the debt outstanding ratio to GDP will be constant from 2024, functioning as a commitment device to rule out the violation of fiscal solvency in their analysis. They clarify that the tax and social security burden to GDP will increase up to $60 \%$ (benchmark calculation) in 2050 under the aforementioned fiscal rule. Furthermore, if the tax and social security burden to national income, which is employed in the official document of the Ministry of Finance, is used as an indicator of the burden, it amounts to about $80 \%$. Second, Hansen and Imrohoroglu [30] implemented a simulation until 2010 based on a simple dynamic general equilibrium (DGE) model and conclude that consumption or labor income tax rate (the ratio of government purchases and transfer payments to output) should be $40 \%$ - $60 \%$ to restore sustainability in government debt, which the government obeys as its intertemporal budget constraint. 
The simulation based on some theoretical models also implies that future generations in Japan will bear the burden of fiscal debt as compared to the past generation in order to maintain the sustainability of government deficit.

\section{Tipping Point of a Fiscal "Crisis"}

Studies introduced in Section 2 do not use the open economy model and exclude the effects of foreign factors.

Recent research by Hoshi and Ito [1] shows that with no government action, debt will likely exceed the amount of private sector financial assets in the near future even if Japan's current public financial condition is not on the verge of a crisis. They suggest that the new JGBs would not be sold at low interest rates; instead, the interest rate of JGBs would rise. Hoshi and Ito [1] define this as a "crisis," and propose a gradual increase in tax rates to avert the "crisis."

The findings of Hoshi and Ito [1] are summarized as follows. First, Japan's abundant household assets, which contribute to the low and stable JGB yields, have for long financed Japan's debt. Second, Hoshi and Ito [1] argue that if private savings decline and government debt continues to increase, debt will reach the level of private sector savings. They predict that although the results are different and dependent on the scenario, the amount of JGB will exceed the private sector's financial assets in the years between 2020 and 2024. As a result, since the share of foreign investors increases, interest rate will rise as shown in Tokuoka's [3] study, which attributed the cause of the low-interest rate to a home bias of the Japanese investors. ${ }^{7}$ However, note that although Hoshi and Ito [1] posit this following the results by Tokuoka [3], they did not predict how the increase in the share of foreign investors for the JGB affects its yields.

\section{Coordination Problem in the JGB Market}

The Japanese government had exerted direct control over the allocation of JGBs. Until 1964, no government bonds were issued, in line with recommendations of the Dodge line. As early as 1953, public corporations issued bonds at artificially low rates. The bond market did not clear because the government organized a syndicate of banks, which purchased public corporation bonds. The Bank of Japan repurchased the bonds after one year. However, the government gradually lost its influence though the 1980s and the syndicate was formally abolished in 2006. The Trust Fund Bureau (TFB) played an important role in alleviating the coordination problem in recent years. ${ }^{8}$

However, in 1998, the Japanese Finance Minister announced that the TFB funding would not be used to buy JGBs (78\% reduction from previous year).

\footnotetext{
${ }^{7}$ Moreover, Matsuoka and Terada [31] also predict the size of interest rate accompanying the increase in the share of foreign investors. They show that according to OECD data, when private saving minus debt is $1.05 \times \mathrm{GDP}$, bond yields tend to go up more rapidly with additional debt. They predict that JGB yield will be $10 \%$ in $2018-28$, while the current JGB yield is around $0.5 \%$.

${ }^{8}$ The TFB collected funds from public pensions and postal saving. The Ministry of Finance (MOF) used these funds to purchase JGBs, and this gave rise to low JGB yield.
} 
Onji et al. [2] document this TFB shock, and show that it accounted for a 0.50 percentage point increase in JGB yields. They also point out that the total withdrawal of postal saving fund is estimated to lead to a 0.32 percentage point increase. The announced change in the financial policy affected the risk premium of buyers.

There is no doubt that the block public holding historically mitigates a potential coordination problem among investors, as shown by Morris and Shin [4], and thereby reduces risk premiums. However, Onji et al. [2] are concerned that even if low JGB yields can be attained with public financial institutions such as postal saving and public pensions holding a certain fraction of marketable JGBs, the JGB market may become volatile once the government withdraws from the JGB purchase.

\section{Conclusion and Discussion}

Reflecting the unprecedented debt accumulation over the past two decades, many researchers are concerned about the sustainability of government deficit and the possibility of a sovereign debt crisis developing in Japan. This paper reviews the related studies through a threefold approach: sustainability problem, relations with foreign investors, and coordination problem in the JGB market.

Researchers concerned with sustainability unanimously agree that the Japanese government will have to generate sufficient fiscal surplus for achieving sustainability. Moreover, when the share of foreign investors increases, as indicated by Tokuoka [3] and Hoshi and Ito [1], the surge in JGB bond yields is apprehended, and it may induce the crowding-out of private capital formation or reduce non-interest spending owing to the increase in interest rate payment. In addition, following the results of Onji et al. [2], the JGB market may become volatile once government financial institutions quit their role of primary purchasers of JGBs. This could also prove detrimental to the macro economy as well as the government budget.

However, there is yet some scope for researchers to examine the underlying fiscal problems in Japan. First, there have been many studies focusing on the general government, but very few examine the relationship with monetary policy. Among the studies introduced in our paper, Doi et al. [17] examine the influence of monetary policy by emphasizing arguments related to the fiscal theory of price level (FTPL). ${ }^{9}$ In light of the Bank of Japan's move of bulk buying of JGBs after 2012, researchers should pay more attention to the interaction between monetary and fiscal policy. Second, very few predictions have been made by employing theoretical models on the relationship between home bias and JGB holdings. Hoshi and Ito's [1] analysis is not based on the micro foundation macroeconomic model, and it does not capture the behavior of each economic

${ }^{9}$ Matsuoka [32] examines the "fiscal limit"-the point beyond which taxes and government expenditures can no longer adjust to stabilize the value of government debt-in the Japanese economy. However, since Matsuoka [32] does not model the monetary policy authority, his framework does not necessarily deal with the interaction between monetary and fiscal policy in the context of FTPL. 
agent accurately. As reviewed by Coeurdacier and Rey [33], some theoretical frameworks explain home bias in the international financial market. A rapidly aging population, which we also mention in Section 2.1, will undoubtedly reduce private sector savings, and this may increase foreign investors' share in JGBs. Researchers are urged to examine and make an inference on how this affects the JGB market using some micro foundation macroeconomic models.

\section{Acknowledgements}

The authors would like to thank two anonymous referees, Seo-Young Cho, Shigeyuki Hamori, Bernd Hayo, Kentaro Iwatsubo, Yuji Kawano, Akihiro Kawase, Shigeto Kitano, Eiichi Miyagawa, Katsuyoshi Nakazawa, Yoshiki Ogawa, Masayuki Tamaoka, Hajime Yamada, Setsuo Yamaki, and participants of the workshop held in Kobe University and Toyo University. The Japan Society for the Promotion of Science (Grant-in-Aid for Scientific Research \#16H03637 \& \#17K03764) has supported this work financially. The usual disclaimer applies.

\section{References}

[1] Hoshi, T. and Ito, T. (2012) Defying Gravity: How Long Will Japanese Government Bond Prices Remain High? National Bureau of Economic Research, No-w18287.

[2] Onji, K., Kameda, K. and Akai, N. (2012) Preestablished Harmony: The Japanese Government's Demand for Japanese Government Bonds. Japan and the World Economy, 24, 207-214. https://doi.org/10.1016/j.japwor.2012.03.001

[3] Tokuoka, K. (2010) The Outlook for Financing Japan's Public Debt. International Monetary Fund WP, 2010, 24. https://doi.org/10.5089/9781451962260.001

[4] Morris, S. and Shin, H.-S. (2004) Coordination Risk and the Price of Debt. European Economic Review, 48, 133-153. https://doi.org/10.1016/S0014-2921(02)00239-8

[5] Miyazaki, T. (2014) Fiscal Reform and Fiscal Sustainability: Evidence from Australia and Sweden. International Review of Economics and Finance, 33, 141-151. https://doi.org/10.1016/j.iref.2014.04.002

[6] Bohn, H. (2008) The Sustainability of Fiscal Policy in the United States. In: Neck, R., and Sturm, J.E., Eds., Sustainability of Public Debt, MIT Press, Massachusetts, 15-49. https://doi.org/10.7551/mitpress/9780262140980.003.0002

[7] Hamilton, J.D. and Flavin, M.A. (1986) On the Limitations of Government Borrowing: A Framework for Empirical Testing. American Economic Review, 76, 808-819.

[8] Trehan, B. and Walsh, C.E. (1991) Testing Intertemporal Budget Constraints: Theory and Applications to U.S. Federal Budget and Current Account Deficits. Journal of Money, Credit and Banking, 23, 206-223. https://doi.org/10.2307/1992777

[9] Hakkio, C.S. and Rush, M. (1991) Is the Budget Deficit "Too Large?" Economic Inquiry, 29, 429-445. https://doi.org/10.1111/j.1465-7295.1991.tb00837.x

[10] Quintos, C.E. (1995) Sustainability of the Deficit Process with Structural Shifts. Journal of Business and Economic Statistics, 13, 409-417.

[11] Bohn, H. (1998) The Behavior of U.S. Public Debt and Deficits. Quarterly Journal of 
Economics, 113, 949-963. https://doi.org/10.1162/003355398555793

[12] Fukuda, S. and Teruyama, H. (1994) The Sustainability of Budget Deficits in Japan. Hitotsubashi Journal of Economics, 35, 109-119.

[13] Doi, T. and Nakazato, T. (1998) Sustainability of Central and Local Government Bonds. Financial Review, 47, 76-105. (In Japanese)

[14] Perron, P. (1989) The Great Crash, the Oil Price Shock, and the Unit Root Hypothesis. Econometrica, 57, 1361-1402. https://doi.org/10.2307/1913712

[15] Ono, H. (2008) Searching for Non-linear Effects and Fiscal Sustainability in G-7 Countries. Applied Economics, 15, 457-460.

[16] Sollis, R. (2004) Asymmetric Adjustment and Smooth Transitions: A Combination of Some Unit Root Tests. Journal of Time Series Analysis, 25, 409-417. https://doi.org/10.1111/j.1467-9892.2004.01911.x

[17] Doi, T., Hoshi, T. and Okimoto, T. (2011) Japanese Government Debt and Sustainability of Fiscal Policy. Journal of the Japanese and international economies, 25, 414-433.

[18] Ihori, T., Nakazato, T. and Kawade, M. (2003) Japan's Fiscal Policies in the 1990s. The World Economy, 26, 325-338. https://doi.org/10.1111/1467-9701.00525

[19] Ball, L., Elmendorf, D.W. and Mankiw, G.N. (1998) The Deficit Gamble. Journal of Money, Credit and Banking, 30, 699-720. https://doi.org/10.2307/2601125

[20] Oguro, K. (2009) An Investigation on the Fiscal Deficit as a Gamble: Focus on the "Uncertain" Economic Growth Rate and Interest Rate. JCER Economic Journal, 60, 19-35. (In Japanese)

[21] Hosono, K. and Sakuragawa, M. (2011) Fiscal Sustainability in Japan. Journal of the Japanese and International Economies, 25, 434-446.

[22] Arai, R. and Nakazawa, M. (2014) A Numerical Analysis of Japan's Fiscal Sustainability in a Simple OLG Model. Applied Economics Letters, 21, 1194-1197. https://doi.org/10.1080/13504851.2014.916382

[23] Chalk, N.A. (2000) The Sustainability of Bond-Financed Deficits: An Overlapping Generations Approach. Journal of Monetary Economics, 45, 293-328.

[24] Arai, R. and Ueda, J. (2013) A Numerical Evaluation of the Sustainable Size of the Primary Deficit in Japan. Journal of the Japanese and International Economies, 30, 59-75.

[25] Blanchard, O., Chouraqui, J.-C., Hagemann, R.P. and Sartor, N. (1990) The Sustainability of Fiscal Policy: New Answers to an Old Question. OECD Economic Studies, 15, 7-36.

[26] Broda, C. and Weinstein D.E. (2004) Happy News from the Dismal Science: Reassessing the Japanese Fiscal Policy and Sustainability. NBER Working Paper, No. w10988.

[27] Doi, T. (2006) Simulation Analysis on the Future Fiscal Policy Management to Restore the Sustainability of the Government Debt: A Reinvestigation of Broad and Weinstein (2004). RIETI Discussion Paper Series, No. 06-J-032. (In Japanese)

[28] Ihori, T., Kato, R., Kawade, M. and Bessho, S. (2006) Public Debt and Economic Growth in An Aging Japan. In: Kaizuka, K. and Alan, K., Eds., Tackling Japan's Fiscal Challenges, Palgrave Macmillan, New York, 30-68. https://doi.org/10.1057/9781137001566_3

[29] Auerbach, A. and Kotlikoff, L. (1987) Dynamic Fiscal Policy. Cambridge University Press, Cambridge. 
[30] Hansen, G. and Imrohorolu, S. (2016) Fiscal Reform and Government Debt in Japan: A Neoclassical Perspective. Review of Economic Dynamics, 21, 201-224.

[31] Matsuoka, H. and Terada, S. (2012) Growing Sovereign Risk May Boost JGB Yields to $10 \%$, with Foreign Holdings Seen Rising to 20\%-30\% Sometime between 18 and 28. JCER Staff Report, 2012-03.

[32] Matsuoka, H. (2015) Fiscal Default and Sovereign Default Risk in Japan. Journal of the Japanese and International Economies, 38, 13-30.

[33] Coeurdacier, N. and Rey, H. (2012) Home Bias in Open Economy Financial Macroeconomics. Journal of Economic Literature, 51, 63-115.

https://doi.org/10.1257/jel.51.1.63 